\title{
Comparison of Ancient Greek Art and Ancient Roman Art
}

\author{
Keyang Wang*
}

Shanghai, Song Jiang 201612, China,

18917359065@189.cn

\begin{abstract}
This paper discusses about similarities and differences between ancient Greek art and ancient Roman art from several aspects, such as location, politics, cultural effects and historical factors. It also talks about what techniques did ancient Greek artists and ancient Roman artists use in their art works. How the art of ancient Rome was inherited from the art of ancient Greece, and what the differences between them. In a nutshell, Ancient Greek artists more focus on individualism and idealism, whereas ancient Roman artists more focus on realism and highlighting the spirits of their rulers. In this paper, I will seek for the cultural and artistic characteristics of these two ancient great countries.
\end{abstract}

Keywords: comparison, ancient, Greece, Rome, art

\section{INTRODUCTION}

The art of ancient Greece and Rome directly influenced the later art of Europe, which has had an important impact on the carving techniques and aesthetics since the Renaissance. Even now, its influence has expanded to the field of contemporary art and architectural culture. There are great similarities between ancient Greek art and ancient Roman art. It is generally believed that ancient Roman art is the learning and inheritance of ancient Greece, many artistic works of ancient Rome have reflected the artistic works of ancient Greek. Both are the precious pearl of ancient European art. However, ancient Greece and Rome have different cultures and ideas after all, and there must be differences in the art produced in different environments.

The development of ancient Roman art was that when the ancient Romans conquered many countries with prosperous culture and art, such as ancient Greece, they robbed and transported a large number of art works from ancient Greece and other countries, especially sculpture and painting, to ancient Rome as booty. At the same time, many well-educated artists and craftsmen were concentrated in ancient Rome as slaves and hostages. The Romans conquered Greece with military, while the Greeks conquered Rome with art. Nevertheless, there are some changes in Roman art.

\section{COMPARISON OF THE IDEAS BETWEEN ANCIENT GREECE ART AND ANCIENT ROMAN ART}

\subsection{Ideas of ancient Greek art}

\subsubsection{The Doryphoros of Polykleitos}

The Doryphoros of Polykleitos (as shown in Figure 1) is a famous bronze statue during the hectic time of Greek carving art (460-416 BC). The author Polykleitos was one of the most famous sculptors during that period. He was good at expressing the image of young athletes and he used to use bronze as material to create his works.

The Doryphoros of Polykleitos depicts a strong and muscular young man, whose body length to head ratio is 7 to 1 . After a long-term research on the proportion of human body, the author believes that the most ideal and perfect proportion of human body is that the ratio of whole body to head is 7 to 1 . It is in accord with the aesthetic conceptions of the Greece society at that time, even the sculptors at that time called this statue "rule", it means that they regard it as the rule and model of body Human body aesthetics. 


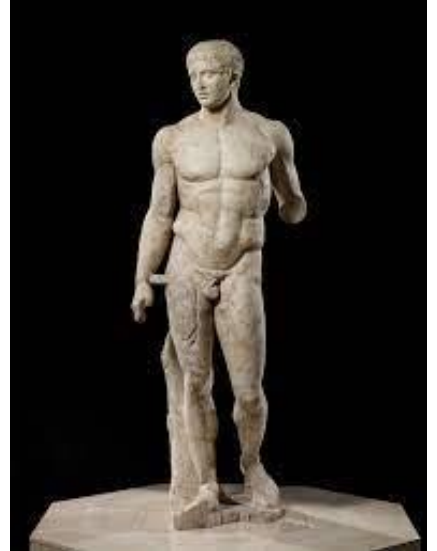

Figure 1 The Doryphoros of Polykleitos From: https://collections.artsmia.org/ the-doryphorosunknown-roman/

\subsubsection{Culture factor of ancient Greek art}

The Greek peninsula is located at the end of southern Balkans's peninsula, the southeast is facing ancient Egypt and West Asia across the sea, which makes it very convenient for ancient Greece to accept the earlier civilization of other countries. The ancient Egyptians created many exquisite works of wood carving, stone carving and bronze carving, they formed skilled carving techniques very early. Greece's geographical situation led to its unsatisfactory agricultural development, so the ancient Greeks developed their navigation, and it became an important pillar of the social economy of ancient Greece, which enabled the ancient Greeks to have a broad vision and form their own style in the contact between Egyptian civilization and oriental culture. "From the middle of the seventh century BC, the Greeks carved large figures out of marble. The inspiration and the system of proportion that they used to make the statue obviously came from Egypt, but there was something more than inspiration that came from Egypt, and that was skill." $[1]$

Although the natural conditions of the Greek peninsula were unfavourable to agricultural production, it was rich in marble, clay and many metal minerals, which provided rich raw materials for the development of ancient handicraft industry. "Bronze crafts were generally related to the statues of gods. The ancient Greeks usually did not make patriots unless they were worthy long-term memorial for some special reasons. For example, the athletes who won in Olympia. If a person has won three victories, sculptors will make an accurate statue for him. These statues are called 'Iconicae'.'[2] The ancient Greeks attached great importance to sports activities and literatures, so they had high achievements in literature and sports. Their literary myths and heroic epics were considered to be the earliest source of European literature. The highly developed literature and sports activities in ancient Greece had a great impact on Sculpture Art: firstly, the ancient Greeks formed a character of paying attention to real life and pursuing romance in literary and sports activities, and formed a specific cultural aesthetic standard; Secondly, it provides a large number of themes, stories and characters for sculpture. Some exquisite works are mostly characters in literary works or winners in sports activities.

The ancient Greeks' pursuit of art is idealized, so the ancient Greeks often take "beauty" and "perfect" as the highest standard of sculpture.

\subsection{Ideas of ancient Roman art}

\subsubsection{Augustus of Prima Porta}

Augustus was created as a hero, his sculptures were usually made lofty. Augustus created a relatively stable political situation and laid the foundation for the prosperity of the early Roman Empire.

Augustus of Prima Porta (as shown in Figure 2) is now collected in the Vatican Museum, it is a copy of the original work made about 15A.D. This white marble statue is 2.04 meters high, and in this work, Augustus is dressed in military uniform and armor, his chest is filled with reliefs. This statue portrays the image of the founder of the Roman Empire. Augustus is shown as a military commander, he holds the sceptre in his left hand, his right hand is raised and pointed forward, just like commanding the majestic Roman army. Augustus is dressed in gorgeous Roman armor, and the patterns on the armor symbolize that the Roman Empire 's rule over the world. Augustus is barefoot and has a little Cupid at his right foot, which shows that he is not only a great commander, but also a benevolent sovereign. The expression on Augustus' face is grim and calm, it reveals the dignity and nobility of the emperor. The style of the whole statue is realistic, and the appearance of the character is vivid, but it has a strong tendency to idealize, which is obviously saw that the artistic purpose of praising the emperor.

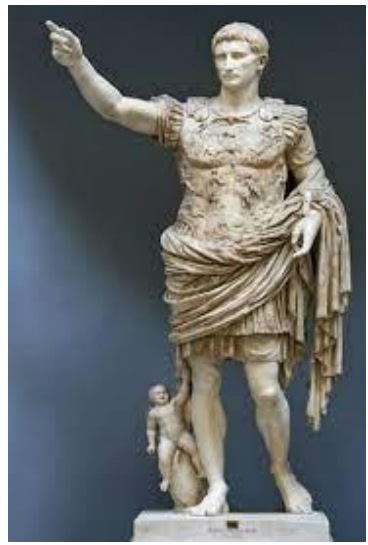

Figure 2 Augustus of Prima Porta From: https://commons.wikimedia.org/wiki/File:StatueAugustus.jpg 
The posture and artistic expression of the statue are obviously imitating the sculptures of ancient Greece. The ancient Romans chose The Doryphoros of Polykleitos, which is the representative work of the Greek classical period, as the basic framework of Augustus of Primaporta, and made some changes to make it more in line with the aesthetic taste of Roman society at that time. The posture of the Doryphoros of Polykleitos cannot perfectly show the emperor's wise judgment and formidable execution, so they made a little adjustment to the character's posture. Roman artists turned the emperor's head to make his eyes look like the direction of his raised right hand, so that the statue had a focus, and effectively reflected the emperor's heroic and decisive character. Because of this adjustment, it changed the standard that Greek art emphasized balance and perfection, and more vividly showed the majesty of the emperor.

\subsubsection{Culture factor of ancient Roman art}

Like ancient Greece, ancient Rome originated from the peninsula. Ancient Rome originated in the Italian peninsula, which had fertile plains and rivers with sufficient water. It was very suitable for agriculture and animal husbandry, also its territory was rich in mineral resources. Under the influence of surrounding civilization, the handicraft industry in ancient Rome was also developing and progressing. However, compared with ancient Greece, ancient Rome was less affected by external civilization. "Rome did not have superior navigation conditions like Greece, so it could only develop on the limited land of Italy and the western Mediterranean. It had little chance to accept the advanced civilization of the eastern Mediterranean. Therefore, it developed late and formed the unique development path of Rome." [3] With the gradual expansion of the territory of ancient Rome, the foreign trade of ancient Rome also became very prosperous, which also made the ancient Roman civilization gradually absorb some achievements of Oriental civilization, and the Roman civilization also had varying degrees of impact on other aeras. As Etruria and ancient Greece were eventually annexed by ancient Rome, they had a lot of influence on the art of ancient Rome, especially the Greek carving art played an important role in promoting the development of ancient Roman carving art. "They adored Greek art and customized many copies of sculptures and paintings, many of which are the only source for us to understand the Greek original works." (Woodford, The Art of Greece and Rome (Cambridge Introduction to the History of Art) p86) Because of the close geo-culture with ancient Greece, the ancient Roman sculpture art can develop on the basis of ancient Greek art.

However, the culture variation led to different artistic atmosphere and trend between ancient Greece and ancient Rome. The Romans were keen to build large- scale public facilities, such as public baths, lounges, arenas, gardens, and libraries, etc. a series of Roman architecture also developed Romanesque sculpture and gave birth a large number of sculptures with Roman local cultures. The emergence of Roman portrait was related to sacrificing ancestors. At that time, many families which were above the middle class, especially aristocrats, often put masks, which were made by imitating their ancestors' faces, in the cabinet of the reception room. These masks were generally used for sacrificial activities. With the development of handicraft industry and commodity economy, portrait has replaced mask carving gradually.

The artistic concept of ancient Rome is completely different from ancient Greece. Military culture makes the image of ancient Roman art works tougher and more prominent in personal spirit and personality. It can be seen form popular sculpture works that most of the characters in ancient Greek sculpture are naked, which is intended to show the strength of the human body and the beauty of body lines, while most of the characters in ancient Roman sculpture are aristocrats in gorgeous clothes, which is intended to publicize the spirit and spiritual power of great heroes. "In Rome, what is really popular is the sculpture of knights, whose style is undoubtedly from Greece."[2] Ancient Rome established its empire by expansion, in this process, it formed an aggressive culture which is advocating force and the worship of ancestors with outstanding achievements. Therefore, the figures and statues in ancient Rome are very different from those in Greece. Because of the extraordinary worship of the deadee of their ancestors, the ancient Romans often engraved the statues of their ancestors' faces and worshipped them in ancestral temples, which led to the fact that the ancient Roman statues were less imaginative than the Greek statues, and the characters' expressions and body language were much more serious and monotonous. Different from the romantic and aesthetic artistic pursuit of ancient Greece, the core feature of ancient Roman culture was "seeking truth and application", and this principle reflected completely in the art of sculpture. Almost all ancient Roman carving works were made according to actual needs. These works existed not only for beauty and decoration. Their publicity and practicality had already exceeded the aesthetic value in the ancient Roman concept.

\subsection{How did political and historical factors affect the differences between ancient Greek art and ancient Roman art}

\subsubsection{Ancient Greece}

Whether in ancient Greece or Rome, their carving art is inseparable from their political system. The Democratic deliberative system under the city-state 
system had a greatest impact on ancient Greek civilization. The democratized political environment was deeply rooted in the ideas of ancient Greece. Residents maintained a simple and plain feeling on art and external civilization. When artists create their works, they are usually restricted by political factors and environments. Therefore, most of the ancient Greek works are humanized gods and heroes.

Ancient Greece can be roughly divided into five periods: "Aegean Civilization", "Homer's era", "Archaic period", "Classical Period" and "Hellenization period". The last period is during the era of Macedonian rule, which is called the "Hellenization period". Wars usually are the most common way for spread different cultures in the past. The conquest of ancient Greece by the Macedonian Empire led to the collision between ancient Greek culture and Eastern civilization and formed a "Hellenistic period". Under the dictatorship of Alexander the Great, the Greek art had a different aesthetic concept from the previous emphasis on the expression of characters and idealize beauty, such as the Statue of Athena. The image of sculpture not only shows the tenderness of, but also shows the image of Athena's brilliance and perseverance. It expresses more the characteristics of human nature and less divinity, which shows that the sculpture art has moved towards secularization during the Hellenistic period. ${ }^{[4]}$

\subsubsection{Ancient Rome}

"Strabo, a geographer in the Augustan era, once praised the Greeks for their skillful integration of their cities and environment and set off the beauty of architecture with those natural ports and landscapes. In contrast, he thought the Romans were more pragmatic: they were mainly great builders of roads, diversion canals and drainage pipes. If necessary, they would also

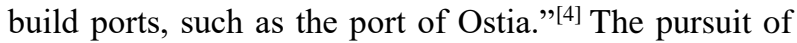
art in ancient Greece was perfectionism and humanistic spirit, while ancient Romans were focus on the practicability. However, it does not mean that Roman works do not have artistry, the Romans also had a eagle eye for the proportion of harmony and perfection. Vitruvius had emphasized that architecture must be attractive, "When the appearance of the building is beautiful and pleasant, and the proportion of details conforms to the correct balance, the principle of beauty will be maintained."[5]

In addition, the parliamentary republic and imperial autocracy in Rome were a system of high control over the people. The dictator's highly centralized rule made the people's weak self-consciousness, and the people been at the monarch's command, also heroism ran rampant. Most of the works in ancient Greece were gods and heroes, while majority of the sculptures in ancient Rome were themes that praised heroes and recorded historical stories. The ancient Romans added impure utilitarian factors to most of their works in order to safeguard the benefits of the ruling class, which led to the weaker artistic creativity of ancient Roman sculpture than that of ancient Greece.

Unlike ancient Greece, ancient Rome did not form distinct artistic characteristics with different historical periods. The development of ancient Rome's sculpture art depended on its continuous expansion to the surrounding city states. It absorbed the excellent achievements of other civilizations, also maintained its own tradition and aesthetic concept. Therefore, there was no obvious boundary to distinguish the artistic characteristics in different periods.

The civilization history of ancient Rome can be traced back to the "Etruria period", which was from the 8 th century BC to the 6th century BC. From about the middle of the eighth century $\mathrm{BC}$, the Etruria residents absorbed the civilization of ancient Greece and the East, created the "Etruria civilization" and spread in the Italian peninsula at that time, which had an important impact on the ancient Roman civilization. In the 3rd century BC, the Etrurians were conquered by the Romans, and their culture was completely integrated into Rome.

From 509 BC to $30 \mathrm{BC}$ was the "Republic period" of ancient Rome, the name of the Roman regime at that time was "the Senate and the Roman people". Also, this period is an era of the continuous development and expansion of the Roman Republic. In about 451 BC, the "Decemviri", which was composed of nobles and civilians promulgated a code and engraved it on ten tables; In $450 \mathrm{BC}$, two more tables were added, which is the "Lex Duodecim Tabularum". The "Lex Duodecim Tabularum" made the free people become equal in the scope of "private law" and limited the judicial autocracy and privilege of the nobility. The "Lex Duodecim Tabularum" was basically a compilation of Roman basic laws and regulations, but it ultimately safeguarded the profits of the nobility and the rich. Roman carvings are often used on such practical works, Roman art was to serve the Romans and express the will of the ruling class.

The carving art of ancient Rome reached its peak during " The Roman Empire Period”, and many famous carving works were also born during this period. In 146 $\mathrm{BC}$, Rome conquered the whole of Greece. Ancient Greece's brilliant civilization achievements, abundant artistic works, and highly skilled artists all belong to Rome, which made the development of ancient Roman art more prosperous.

\section{CONCLUSION}

Ancient Roman art was mainly developed by inheriting ancient Greek art, so their artistic styles have numerous similarities. Firstly, they would analyse the creation object and have a set of standards. The body of human sculpture would follow the most perfect 
proportion, also, the body structure and facial expressions pursued the real effect. Secondly, sculpture works would pursue a harmonious and idealized beauty. Whether The Doryphoros of Polykleitos or the Augustus of Primaporta, their artistical idea was the same - the components must be harmonious. Thirdly, ancient Greek art and ancient Roman art had some characters in common because of their belief in similar myths and devout religious attitude. The solemn temples and statues with the same attributes lead to the similarity of their sculpture images. In summary, the art of ancient Greece and ancient Rome showed an inheritance relationship in aesthetics and techniques.

However, there were differences in national culture and political system between ancient Greece and ancient Rome, thus, their artistic works must have some divergences. Ancient Greek sculptures mostly took mythical characters and heroes as the main objects of expression, and the content reflects the thought of humanism, while the ancient Roman sculptures usually took ancestors and warriors as the theme to express the worship and awe of ancestors. In addition, ancient Greek art had a strong romantic colour, it paid attention to imagination and had an aesthetic tendency. However, ancient Roman art pursued realistic and secularization, it paid great attention to the authenticity of details the performance of the character. Moreover, many ancient Roman statues were made for the worship of ancestors, with distinct practicability. The famous Roman architect during the $1^{\text {st }}$ century BC -- Marcus Vitruvius Pollio's the Ten Books on Architecture and his three essential elements of architecture in this book is firmitas, utilitas, and venustas (means "strength", "utility", and "beauty") had a profound and lasting impact, it also reflected the aesthetic concept of the ancient Romans.

\section{REFERENCES}

[1] Woodford Susan.(1982)The Art of Greece and Rome (Cambridge Introduction to the History of Art).Cambridge University Press,Cambridge.

[2] Gaius Plinius Secundus. (1949-1954)Pliny's Natural History. Harvard University Press, London.

[3] Li Yale, Yang Gongle. (1988)The History of Ancient Rome. Jilin University Press, Jilin.

[4 ]Freeman Charles.(2004) Egypt, Greece and Rome: Civilizations of the Ancient Mediterranean. Oxford University Press, Oxford.

[5] Mark Wilson-Jones. (2000) Principles of Roman Architecture. Yale University Press, New Haven and London. 